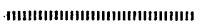

\title{
キャパシタンス法による半導性セラミックス粒界の研究
}

\author{
津田孝一・向江和郎 \\ (株)富士電機総合研究所 荳240-01 横須賀市長坂 2-2-1
}

(1992 年 2 月 13 日受理)

\section{Characterization of Grain Boundaries in Semiconducting Ceramics Using Capacitance Methods}

\author{
Koichi Tsuda and Kazuo Mukae \\ Fuji Electric Corporate Research \& Development, Ltd. \\ 2-2-1, Nagasaka, Yokosuka, 240-01
}

(Received February 13, 1992)

\begin{abstract}
通常, セラミックス粒界の研究手段として, 電子顕微鏡, オージェ電子分光などの機器分析装置が用いら れる。これらの装置により，最近では粒界近傍の格子像が見られるようになってきた。しかし，ZnOバリ スタのような半導性セラミックスでは, 非常に微量な元素や久陥が形成する電気的障壁により特性が決定さ れるため, 機器分析だけでは得られる情報は不十分である。

このような観点から, 最近, キャパシタンスの過渡変化から粒界の情報が得られる DLTS 法, ICTS 法 などのキャパシタンス法が注目されている。こてでは， $\mathrm{ZnO}$ バリスタを中心に，キャパシタンス法の原理， 測定法拉よび最近の展開について解説する。
\end{abstract}

\section{1.はじめに}

従来，セラミックス粒界の評価というと，きまって電 子顕微鏡による粒界近傍の微細構造の観察をさしてい た。最近では, 高分解能透過形電子顕微鏡 (HR-TEM) やオージェ電子分光法 (AES) によって, 粒界近傍の格 子像や元素分布が詳しく調べられるようになってきた。

しかし，表 1 に示すような半導性セラミックス粒界の 電気的性質を利用した材料は，その電気的特性が非常に 微量の元素や欠陥によって形成される電気的障壁による ため，機器分析で得られる粒界の結晶構造や組成の情報

表 1 半導性セラミックスにおける粒界利用

\begin{tabular}{l|l|l}
\hline \multicolumn{1}{c|}{ 品 } & 主 材 料 & 半導体の種類 \\
\hline $\mathrm{ZnO}$ バリスタ & $\mathrm{ZnO}$ & $\mathrm{n}$ 形 \\
\hline $\mathrm{SrTiO}_{3}$ バリスタ & $\mathrm{SrTiO}_{3}$ & $\mathrm{n}$ 形 \\
\hline $\mathrm{PTC}$ サーミスタ & $\mathrm{BaTiO}_{3}$ & $\mathrm{n}$ 形 \\
\hline 粒界層形コンデンサ & $\mathrm{SrTiO}_{3}$ & $\mathrm{n}$ 形 \\
& $\mathrm{BaTiO}_{3}$ & \\
\cline { 2 - 3 } & $\mathrm{SiC}: \mathrm{Be}$ & $\mathrm{n}$ 形 \\
\hline $\begin{array}{l}\text { 高熱伝導・高絶縁性 } \mathrm{SiC} \\
\text { 基板 }\end{array}$ & & \\
\hline
\end{tabular}

だけでは不十分である。このため，別の観点から粒界を 研究する手段が必要となってきた。

$\mathrm{Ge}, \mathrm{Si}$ などの半導体単結晶では, 電極/半導体接合面 にできるキャパシタンスが印加電圧によって変化するて とが知られており，乙の性質を利用して接合の物性を調 へることが古くから行われてきた。その代表的なあのが $\mathrm{C}-\mathrm{V}$ (キャパシタンスー電圧) 法である。その後, キャ パシタンスの過渡応答から接合部の物性を調べる C-t (キャパシタンス-時間) 法が提案された。乙れがキャパ シタンス法と呼ばれる DLTS (Deep Level Transient Spectroscopy) 法 ${ }^{1)}$ や, ICTS (Isothermal Capacitance Transient Spectroscopy) 法2) へと発展し, MOS-FET, レーザーダイオード, a-Si 太陽電池など広範なデバイス 接合の評価に適用されている。

一方，セラミックス粒界の研究にキャパシタンスを用 いたのは比較的新しく，筆者の知るかぎりでは，PTC サーミスタの粒界研究に C-V 法を適用した桑原, 柳田 の報告3) が最も古いあのである。その後発表された変形 $\mathrm{C}-\mathrm{V}$ 法 $^{4}$ は，七ラミックス粓界を定量的に取り扱える形 にしたあので, 現在であドナー密度の評価に広く用いら 
れている。キャパシタンス法に関しては, DLTS 法を $\mathrm{ZnO}$ バリスタに適用し, 粒内準位を研究した正畑ら ${ }^{5)}$, 仁田山ら ${ }^{6)}$ の報告が最初である。その後, ゼロバイアス DLTS 法7)により界面準位の評価が可能となった。ま

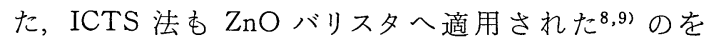
きっかけとして，さまざまな材料でてれを用いた研究が 始まった。

本稿ではキャパシタンス法 (DLTS 法, ICTS 法) に ついて, $\mathrm{ZnO}$ バリスタを中心として, 原理, 測定法およ び最近の展開について述べる。

\section{2. 半導性セラミックス粒界の電子構造と キャパシタンス}

\section{1 粒界の電子構造}

半導性セラミックス粒界の電子構造は粒界に絶縁体か らなる析出層が存在するかどうかにより，二つのモデル が考えられる。

$\mathrm{ZnO}$ バリスタの研究初期には, 粒界に絶縁性析出層 が存在するモデルが提案され，てれに基づく電導機構む 析出層を介した空間電荷制限電流モデルやトンネルモデ ルが議論された。その後, HR-TEM や AES によって 粒界析出層と呼べるような粒界第二層は存在しないて とが確認され，現在では図 1 亿示すような二重ショッ トキー障壁モデルが定説になっている。てのモデルは $\mathrm{ZnO}$ バリスタだけではなく, PTC サーミスタ, $\mathrm{SiC}:$ $\mathrm{Be}$ セラミックスであ支持さ机ている。 $\mathrm{SrTiO}_{3}$ バリス タや BL コンデンサでは粒界析出層の有無については, まだ結論が出ていないように見受けられる。

表 1 で示した材料はすべて $\mathrm{n}$ 形半導体であり，また多 くの材料に図 1 亿示す単純なモデルが適用できるので,

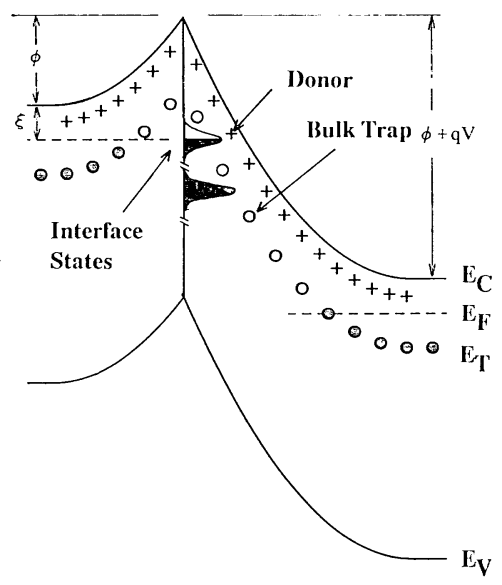

図 1 粒界近傍の電子構造（電圧印加時）
以下の説明は $\mathrm{n}$ 形半導体で単純二重ショットキーモデル について行う。

二重ショットキー障壁は粒界に存在する界面準位と粒 内に存在するイオン化した浅い準位（ドナー）によって 形成される。図1では，乙れらのほかに粒内に存在する 深い準位む示してあるが，乙れについては後述する。

粒界から離机た粒内では，イオン化したドナーの正電 荷と, ドナーから放出された電子の負電荷によって電気 的中性が保たれており，伝導帯はフラットである。てれ に対して, 粒界にアクセプタ形の界面準位があると, 正 に帯電したドナーの影響が現れ，乙のため電気的障壁が 形成される。乙机は, 界面準位のフェルミ準位と粒内の. フェルミ準位を一致させるために粒内の電子をとらえた 界面準位が, 粒内に電子の存在しない領域を形成するた めである。電子の存在しない領域は空乏層之呼ばれ, 絶. 縁性の性質を示す。

\section{2 キャパシタンスと界面準位}

電圧 $V$ を印加したときの順方向側の空乏層幅を $W_{F}$, 逆方向側の空乏層幅を $W_{R}$ とすると, 図1のような二 重ショットキー障壁が作るキャパシタンスは次式で表わ. される。

$$
C(V)=\frac{\varepsilon s A}{W_{F}+W_{R}}
$$

ここで，Esは結晶粒の誘電率， $A$ は接合面積である。 界面準位にとらえられた電荷 $Q_{I S}$ は電荷中性の原理. に従って, 空乏層幅とドナー密度 $N_{D}$ によって決まり 次式で与えられる。

$$
Q_{I S}(V)=q A \int_{W_{F}}^{W_{R}} N_{D} d W=q A N_{D}\left(W_{F}+W_{R}\right)
$$

(1)，(2)式から，キャパシタンスと界面準位にとら. えられている電荷量との関係式 ( 3 )が得られる。

$$
Q_{I S}(V)=A^{2} q \varepsilon s N_{D} \frac{1}{C(V)}
$$

\section{3 キャパシタンスの過渡変化と界面準位}

以上の議論は界面準位にとらえられている電荷の時間. 変化にも適用できる。

界面準位の電荷の過渡変化は, 二つの場合に分けられ る。一つはとらえられていた電子が界面準位から放出さ れる場合 (放出過程) で, あう一つは電子が界面準位に とらえられる場合（捕獲過程）である。

図 2 に示すように, 電圧が卯加されていない場合を定 常状態として，乙れにパルス状の電圧 $V$ を加え定常状態: を乱した後, 再び定常状態へ民る電子の放出過程を考え る。定常状態で界面準位によらえられている電荷量, キャパシタンスを $Q_{I S}(\infty), C(\infty)$, 過渡状態の電荷量, 


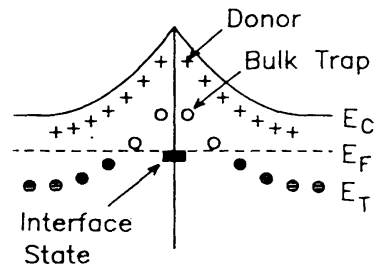

a. Steady state

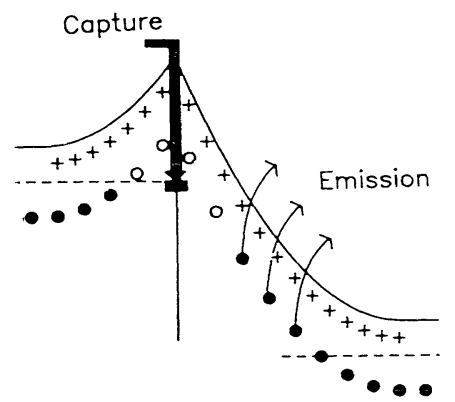

b. During the pulse

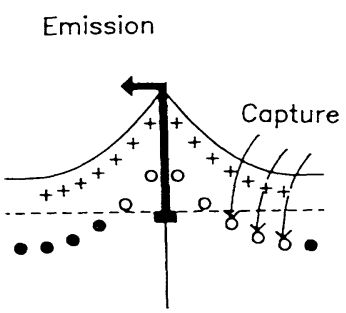

c. Transient state

図 2 粒界での電子の動き

a . 定常状態, b. パルス電圧印加時, c. 過渡 状態

キャパシタンスを $Q_{I S}(t), C(t)$ とすると, (3) 式の関係 から

$$
f(t)=\left(\frac{1}{C(t)}-\frac{1}{C(\infty)}\right)=\frac{Q_{I S}(t)-Q_{I S}(\infty)}{A^{2} q \varepsilon s N_{D}}
$$

が得られる ${ }^{10)}$ 。さらに, 界面準位電荷の変化量は $(5)$ 式 で与えられる ${ }^{11)}$ 。

$$
\begin{aligned}
& Q_{I S}(t)-Q_{I S}(\infty) \\
& \quad=q A \int_{E_{V}}^{E c} N_{I S}(E) p(E) \exp \left[-e_{n}(E) t\right] d E
\end{aligned}
$$

ここで, $N_{I S}(E)$ はエネルギーEにおける界面準位密 度, $p(E)$ は界面準位にある電子の応答率, $e_{n}(E)$ はエネ ルギーEにおける電子の放出速度で,

$$
\begin{aligned}
e_{n}(E) & =N_{C} \sigma_{n}(E) v_{t \dot{n}} g^{-1} \cdot \exp \left(\frac{E-E_{C}}{k T}\right) \\
& =T^{2} \sigma_{n}(E) B \cdot \exp \left(\frac{E-E_{C}}{k T}\right)
\end{aligned}
$$

で与えられる ${ }^{12)}$ 。こてで，Nc は伝導帯の有効状態密 度, $\sigma_{n}(E)$ はエネルギーEにおける電子の捕獲断面積, $v_{t h}$ は電子の熱速度, $k$ はボルッマン定数, $T$ は温度, $h$ はプランク定数, $m_{e}{ }^{*}$ は電子の有効質量, $g$ は縮退 度, $B=4 \sqrt{6} \pi^{3 / 2} k^{2} h^{-3} m_{e}{ }^{*} g^{-1}$ である。

図 2 とは逆の捕獲過程では， $e_{n}$ の代わりに捕獲係数が 用いられる。

以上から界面準位の諸因子とキャパシタンスの関係が わかる。

\section{3. キャパシタンス法の原理と測定法}

\subsection{DLTS 法の原理と測定法}

$$
f(t)=f_{0} \exp \left(-e_{n} t\right)
$$

で記述できるような速度 $e_{n}$ で時間変化をする現象に対 して, DLTS シグナルは,

$$
D\left(t_{1}, t_{2}\right) \equiv f\left(t_{1}\right)-f\left(t_{2}\right)
$$

で定義される。この関数は,

$$
e_{n, \max }=\left(t_{1}-t_{2}\right) / \ln \left(t_{1} / t_{2}\right)
$$

で極值をむつ。

DLTS 法は D.V. Lang によって主に化合物半導体 結晶中の深い準位（バルクトラップ）を評価するために 考案された方法である。ドナー密度に比べバルクトラッ プ密度が非常に少ない場合には，バルクトラップと伝導 帯間の電子の移動はキャパシタンスに比例するため,

Lang は DLTS シグナルを

$$
D\left(t_{1}, t_{2}\right) \equiv C\left(t_{1}\right)-C\left(t_{2}\right)
$$

と定義した ${ }^{1)}$ 。

界面準位の場合には， $Q_{I S}(t)-Q_{I S}(\infty)$ が $(7)$ 式を満 足するので, 試験関数には(4)式が用いられる。しか し, $[C(0)-C(\infty)] / C(\infty) \ll 1$ が成り立つ場合には，(10) 式のように Lang の定義が使える。

$$
\left(\frac{1}{C\left(t_{1}\right)}-\frac{1}{C\left(t_{2}\right)}\right) \fallingdotseq-\frac{1}{C^{2}(\infty)}\left[C\left(t_{1}\right)-C\left(t_{2}\right)\right]
$$

この仮定が成立しない場合には，盲目的に(9)式に従う のではなく，(4)式に基づいた DLTS 測定が必要であ る。

測定は高速のキャパシタンス計を用い, 平衡状態と 過渡状態を 1 秒間化数十回以上繰返し，その信号を平均 化しデータをプロットしながらゆっくりと試料温度を 掃引する。乙のとき, 界面準位に対応して, ある温度 $T_{\max }$ で DLTS シグナルは極值をむつ。 $e_{n, \max } / T^{2}{ }_{\max }$ と $T_{\max }$ とをアレニウスプロットするととにより, 界面準 


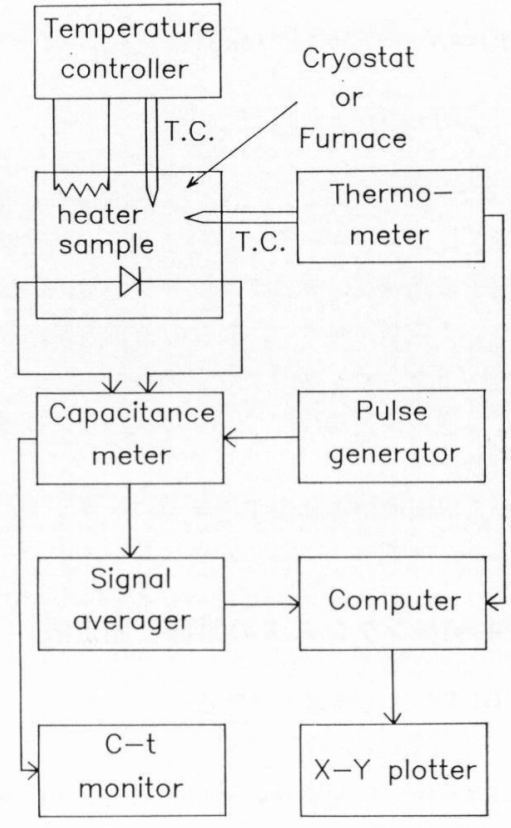

図 3 DLTS 装置の構成

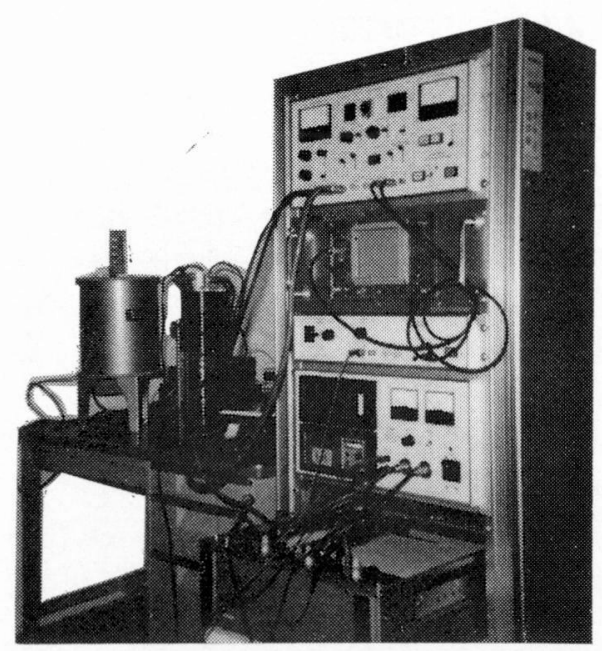

図 4 DLTS 装置の外観

位深さ, 捕獲断面積が求められる。また, DLTS スペ クトルの形から界面準位の分布などがわかる。図 3 に筆 者らの測定システムのブロックダイヤグラム, 図 4 に装 置の外観を示す。

\subsection{ICTS 法の原理と測定法}

(7) 式で与えられる現象に対して, ICTS シグナルは つぎの式で定義される2)。

$$
S(t) \equiv t \frac{d f(t)}{d t}=\frac{d f(t)}{d \ln t}
$$

\footnotetext{
（4）式を試験関数とし，（5)式を代入すると，
}

$$
\begin{aligned}
S(t)= & \frac{-1}{A \varepsilon_{S} N_{D}} \cdot \int_{E_{V}}^{E_{C}} N_{I S}(E) p(E) \\
& \times e_{n}(E) t \cdot \exp \left[-e_{n}(E) t\right] d E
\end{aligned}
$$

となる ${ }^{11,13)} 。 S(t)$ は $e_{n}\left(E_{m}\right) t=1$ のときにピーク值をも つので,

$$
\begin{aligned}
& N_{I S}(E)=N_{I S}\left(E_{m}\right) \exp \left[\gamma\left(E_{m}\right)\left(E-E_{m}\right)\right] \\
& \gamma(E)=\frac{1}{N_{I S}(E)} \cdot \frac{d N_{I S}(E)}{d E}
\end{aligned}
$$

と近似し, E. Yamaguchi の手法 ${ }^{14)}$ を用いると(12)式 は，次式となる。

$$
S_{\max }=\frac{-k T N_{I S}\left(E_{m}\right)}{A \varepsilon S N_{D}} \cdot p\left(E_{m}\right)
$$

測定は, DLTS と異なり一定温度下で $C(t)-t$ 測定を 行い，(11)式にしたがってデータ処理を行う。これから 得られた $e_{n}\left(E_{m}\right) / T^{2}$ と $T$ をアレニウスプロットし, 界 面準位深さ, 捕獲断面積などを求める。

界面準位からの電子放出は比較的ゆっくりしているの で, 低速のキャパシタンス計で測定した例が多いが, ICTS 法では信号処理に微分を行うので，できるだけ短 い時間間隔で, 多くのデータを取り込み, これを平均化 処理をしたほうがノイズが少なくなる。このためには， やはり DLTS 測定と同様に高速のキャパシタンス計を 使用するほうが望ましい。筆者らのシステムでは DLTS 用の高速キャパシタンス計と 10 ビットの高速メモリー を用いている。また, 微分処理は $\Delta t$ 一定で微分した 後, $t$ を掛けるよりも, $\Delta \ln t$ 一定で微分したほうがよ りノイズが少なくなる。

なお, DLTS 法, ICTS 法では, 界面準位だけでなく 粒内準位 (バルクトラップ) む評価するととができる。 粒内準位の評価については多くの文献があるのでそれら を参照していただきたい1,2,5,6,7,11)。

\section{4. キャパシタンス法による最近の界面準位の 研究}

キャパシタンス法の半導性セラミックス粒界研究への 適用は, $\mathrm{ZnO}$ バリスタにおいて始まり, 現在です $\mathrm{ZnO}$ バリスタ以外の発表はそれほど多くない。とこでは主に $\mathrm{ZnO}$ バリスタにおける研究について述べ, $\mathrm{SrTiO}_{3}$ バリ スタなどについては簡単に言及するととに止める。

\section{1 キャパシタンス法による ZnO バリスタ粒界の 研究}

\subsection{1 粒界近傍の粒内準位}

キャパシタンス法による $\mathrm{ZnO}$ バリスタ粒界の研究は 1980 年に発表された正畑らの報告 ${ }^{5)}$ が最初である。彼ら は DLTS 法により, $\mathrm{ZnO}-\mathrm{Bi}_{2} \mathrm{O}_{3}$ 系バリスタの粒界近 傍に存在する二つの粒内準位を見出した。また, 仁田山 
らはおのおのの粒内準位密度を求め, その密度が 1 原子 ppm 以下であるとした6)。さらに，準位の深さと電圧一 電流特性の応答速度を調べ，粒内準位と応答速度に関 係のあるととを報告した。図 $5 ， 6$ は筆者らが $\mathrm{ZnO}$ $\mathrm{Pr}_{6} \mathrm{O}_{11}$ 系バリスタ, $\mathrm{ZnO}-\mathrm{Bi}_{2} \mathrm{O}_{3}$ 系バリスタで得た二つ の粒内準位の DLTS スペクトルとそのアレニウスプ ロットである7)。粒内準位については，その後，表 2 に 示すように, DLTS 法, ICTS 法のキャパシタンス法の ほか，アドミッタンス法などでも調べられ，ほぼ同じ值 が得られている。てのように $0.2 \mathrm{eV}$ と $0.3 \mathrm{eV}$ の粒内 準位は添加物や作製法によらず検出されることから，最 近では，乙の二つの準位は $\mathrm{ZnO}$ そのあのに起因すると 考えられており， $0.2 \mathrm{eV}$ は格子間 $\mathrm{Zn}, 0.3 \mathrm{eV}$ は酸素 欠陥に関係しているとの見方が多い。初期に発表された 報告では，乙れらの粒内準位が劣化や V-I 特性の応答速

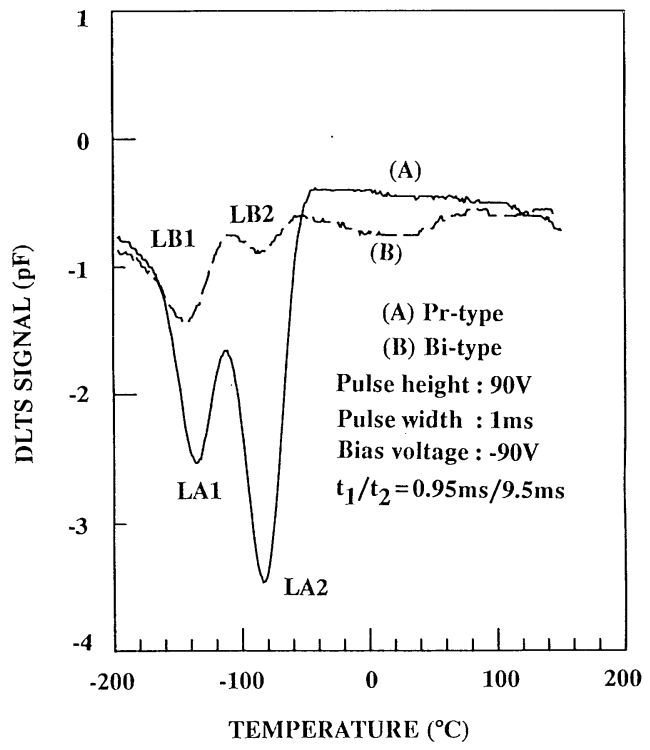

図 う バルクトラップの DLTS スペクトル
度に関与しているとの見方があった。しかし，表 2 で示 したように, $\mathrm{ZnO}-\mathrm{Bi}_{2} \mathrm{O}_{3}$ 系バリスタよりあ $\mathrm{ZnO}_{\mathrm{n}} \mathrm{Pr}_{6} \mathrm{O}_{11}$ 系バリスタのほうが粒内準位が多いにあかかわらず, 応答速度が速く，また劣化む少ないので，てれらの準位 はバリスタ特性には直接関係していないむのと考えられ る。

粒内準位がバリスタ特性にかかわっているかどうかは 別にして，キャパシタンス法では 1 原子 $\mathrm{ppm}$ 以下の粒 内欠陥を非破壊で求めることができ，また得られる情報 が多いので，乙の点では機器分析より優れた方法といえ よう。

\subsection{2 界面準位}

$\mathrm{ZnO}$ バリスタの界面準位はバリスタ特性に直接関係 しているので, 多くの研究者がさまざまな手法で研究し

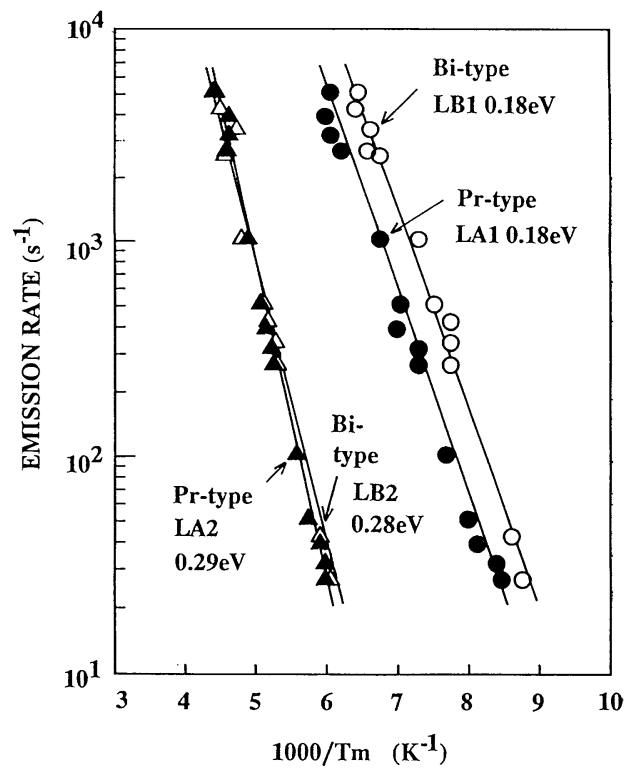

図 6 DLTS スペクトルから得られたアレニウス プロット

表 2 代表的な $\mathrm{ZnO}$ バリスタの粒内準位の性質

\begin{tabular}{|c|c|c|c|c|c|c|}
\hline \multirow{2}{*}{ 発 } & \multirow{2}{*}{ 測 定 法 } & \multicolumn{2}{|c|}{ L 1} & \multicolumn{2}{|c|}{$\mathrm{L}_{2}$} & \multirow[b]{2}{*}{ 備 } \\
\hline & & ${ }^{\text {深 }}(\mathrm{eV})^{\text {さ }}$ & $\begin{array}{c}\text { 密 度 } \\
\left(1 / \mathrm{cm}^{3}\right)\end{array}$ & ${ }_{(\mathrm{eV})}^{\text {さ }}$ & $\begin{array}{l}\text { 密 度 } \\
\left(1 / \mathrm{cm}^{3}\right)\end{array}$ & \\
\hline N. Shokata ほか55) & DLTS & 0.24 & - & 0.33 & - & $\mathrm{ZnO}: \mathrm{Bi}$ 系 \\
\hline A. Nitayama ほが & DLTS & 0.18 & $8.3 \times 10^{15}$ & 0.30 & $9.1 \times 10^{15}$ & $\mathrm{ZnO}: \mathrm{Bi}$ 系 \\
\hline \multirow[t]{2}{*}{ K. Tsuda ほか7) } & \multirow{2}{*}{ DLTS } & 0.18 & $2.2 \times 10^{16}$ & 0.29 & $3.0 \times 10^{16}$ & $\mathrm{ZnO}: \mathrm{Pr}$ 系 \\
\hline & & 0.18 & $1.1 \times 10^{16}$ & 0.28 & $0.7 \times 10^{16}$ & $\mathrm{ZnO}: \mathrm{Bi}$ 系 \\
\hline T. Maeda ほか11) & ICTS & 0.19 & - & 0.29 & - & $\mathrm{ZnO}: \mathrm{Bi}$ 系 \\
\hline J.F. Cordaro ほか & アドミッタンス法 & 0.17 & - & 0.30 & - & $\mathrm{ZnO}: \mathrm{Bi}$ 系 \\
\hline F. Greuter ほか & アドミッタンス法 & 0.19 & $3 \times 10^{17}$ & 0.32 & $2 \times 10^{17}$ & $\mathrm{ZnO}: \mathrm{Bi}$ 系 \\
\hline
\end{tabular}




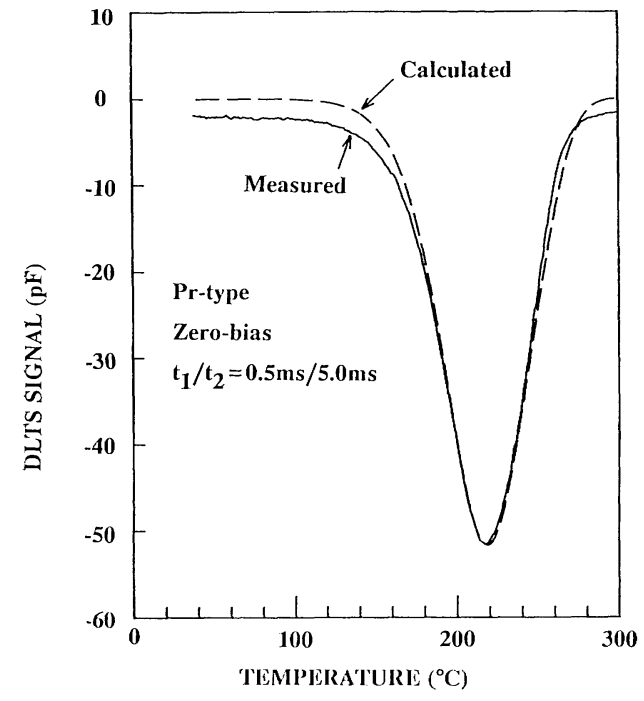

図 7 界面準位の DLTS スペクトル

てきたが，従来の手法では準位の深さを求めることが精 一杯であった。筆者らは, 1984 年に, DLTS シグナル のバイアス電圧依存性から，界面準位と粒内準位を分離

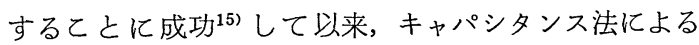
$\mathrm{ZnO}$ バリスタの界面準位の研究に取り組んできた。図 7 はゼロバイアス下での DLTS スペクトルである7。 この研究によって, 界面準位の深さはむちろん, 界面準 位は粒内準位と異なりアクセプター形であることが明ら かになり，また分布む単一準位であるとともわかってき た。図 8 は DLTS 法の結果から推定された粒界近傍の

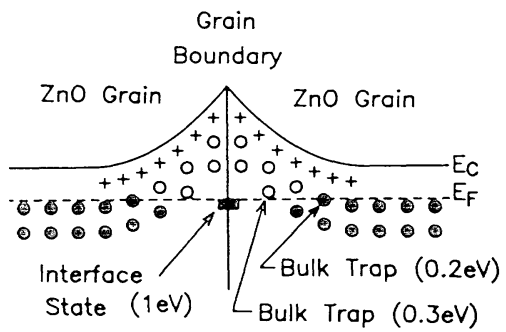

図 8 推定される $\mathrm{ZnO}$ バリスタ粒界の電子構造

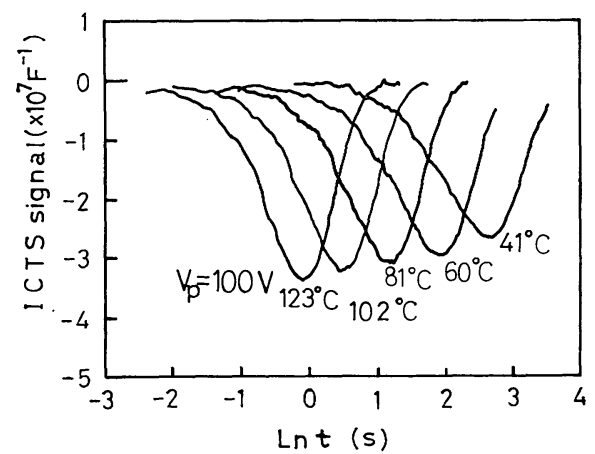

図 9 界面準位の ICTS スペクトル

電子構造である。

界面準位の成因としては,

（1）粒界に析出した $\mathrm{Bi}, \operatorname{Pr}$ などのイオン半径の大き な原子が作る。

(2) 粒界に化学吸着した酸素原子が作る。

との二つの考えがある。筆者らは， $\mathrm{ZnO}$ バリスタが酸 素雲囲気に敏感であるととから, 界面準位の起源は化学 吸着した酸素原子との立場をとっている。図 7 からわか るように, 界面準位の深さが深く, そのため電子の放出 速度が遅いので DLTS 法では $200^{\circ} \mathrm{C}$ 以上の温度が必要 である。高温では，化学吸着した酸素は動きやすく，乙 のため DLTS 法は界面準位の起因を探る方法としては 適切でないと考えられる。筆者らは，現在，DLTS 法よ り低温で界面準位が評価でき，しかも DLTS 法と同様 に高感度でスペクトルが得られる ICTS 法が半導性セ ラミックス界面準位の評価法として最適であると考えて いる。図9は筆者らのシステムで最近得られた ICTS スペクトルである ${ }^{16)}$

粒内準位では発表されたデータはほぼ同じ值である が，界面準位ではさまざまな值が報告されている。この 原因が，試料によるあのか，測定法によるものか現時点 では明確になっていない。

\section{$4.2 \mathrm{ZnO}$ バリスタ以外の研究}

$\mathrm{ZnO}$ バリスタ以外の材料では，まだ発表件数は少な い。表 3 にてれまで発表されている報告を示す。これら

表 $3 \mathrm{ZnO}$ バリスタ以外の材料の発表例

\begin{tabular}{|c|c|c|c|}
\hline 材 & 測 定 法 & 結 & 発 表 者 \\
\hline $\mathrm{SrTiO}_{3}$ バリスタ & DLTS 法 & ブロードな界面準位検出 & 中野由崇ほか \\
\hline PTC サーミスタ & ICTS 法 & 界面準位検出 & 七野修一ほか20) \\
\hline $\mathrm{SrTiO}_{3}$ バリスタ & ICTS 法 & ブロードな界面準位検出 & 秋田千芳ほか211 \\
\hline $\mathrm{SiC}: \mathrm{Be}$ セラミックス & 光 ICTS 法 & 界面準位観測 & 田中 滋ほか22) \\
\hline $\mathrm{SrTiO}_{3}$ バリスタ & DLTS 法 & 準位検出 & 友景 肇ほか23) \\
\hline $\begin{array}{l}(\mathrm{Ba}, \mathrm{Sr}) \mathrm{TiO}_{3} \\
\mathrm{PTC} \text { サーミスタ }\end{array}$ & ICTS 法 & - & 高橋智春ほか24) \\
\hline
\end{tabular}


についてはまだ研究が始まったばかりで, 定量的な取り 扱いが行われるほど研究は進んでいるとはいいがたい。

\section{5.おわりに}

DLTS 法や ICTS 法による半導性セラミックス粒界 の評価法は， $\mathrm{ZnO}$ バリスタが率引車となって，少しず つ改良され，現在では，準位深さだけではなく，準位密 度や捕獲断面積など，界面準位の物性值が定量的に把握 され始めている。乙のまま研究が続けば， $\mathrm{ZnO}$ バリス タに関しては界面準位の起源に決着がつく日もそう遠く ないと思われる。

一方, $\mathrm{SrTiO}_{3}$ バリスタなど, $\mathrm{ZnO}$ バリスタ以外の材 料ではまだデータの蓄積が少なく, より多くの研究が必 要と思われる。最近，乙れらの材料においてあ，キャパ シタンス法による研究が増えているので, 近い将来定量 的な議論がなされるに違いない。

半導性セラミックスへのキャパシタンス法の適用に関 しては，定量的な議論をしている報告は少なく，そのた め筆者らの考えを中心としてまとめた。拙稿を足掛かり として, キャパシタンス法がさらに発展すれば幸いであ る。

\section{文献}

1) D. V. Lang: J. Appl. Phys. 45, 3023 (1984).

2) H. Okushi and Y. Tokumaru: Jpn. J. Appl. Phys. 19, L 335 (1980).

3) 桑原 誠, 柳田博明: 窯協誌 81, 334 (1973).

4) K. Mukae, K. Tsuda and I. Nagasawa: J. Appl. Phys. 50, 4475 (1979).

5) N. Shohata, T. Matsumura and T. Ohno: Jpn. J. Appl. Phys. 19, 1793 (1980).

6) A. Nitayama, H. Sakai and T. Ikoma: Jpn. J. Appl. Phys. 19, L 743 (1980).

7) K. Tsuda and K. Mukae: Mat. Sci. Mono- graphs, 3 B (Elsevier Science Publ. 1987) P. 1781. 津田孝一, 向江和郎: 日セラ協誌 $\mathbf{9 7}$, 1211 (1989).

8）前田孝雄, 高田雅介: 日セラ協秋季シンポ予稿 (1988) p. 35.

9）津田孝一, 向江和郎：日セラ協秋季シンポ予稿 (1988) p. 37.

10）向江和郎, 永沢郁郎 : 春季応物予稿 (1979) p. 405 .

11）前田孝雄，高田雅介：日セラ協誌 $\mathbf{9 7}, 1219$ (1989).

12）生駒俊明, 奥村次徳 : 電子通信学会誌 64, 59-66, 195-202, 279-285 (1981).

13）徳丸洋三, 大串秀世 : 信学技報, SSD 81-29, 75 (1981).

14) E. Yamaguchi : Jpn. J. Appl. Phys. 21, 1628 (1982).

15）津田孝一, 向江和郎 : 日セラ協 電子材料研究討論 会予稿 (1984) p. 18.

16）津田孝一, 向江和郎: 日セラ協 電子材料研究討論 会予稿 (1991) p. 51.

17) J.F. Cordaro: "Advances in Varistor Technology" (Ame. Ceram. Soc. 1990) p. 125.

18) F. Greuter, G. Blatter, M. Rossinelli and F. Stucki : ibid. p. 31.

19）中野由崇, 高橋智春, 一ノ瀬昇 : 日セラ協年会予 稿 (1990) p. 203., Y. Nakano and N. Ichinose: J. Mater. Res. 5, 2910 (1990).

20）七野修一, 高田雅介：日セラ協秋季シンポ予稿 (1990) p. 308.

21）秋田千芳, 柴垣茂樹, 伊藤憲治, 田中順三, 羽田 肇, 白崎信一: 日セラ協 電子材料研究討論会予稿 (1990) p. 31.

22）田中 滋, 高橋 研, 鈴木康隆, 秋田千芳, 大橋 直樹, 大串秀世, 和田芳樹, 羽田肇, 田中順三: 日七ラ協年会予稿 (1991) p. 519.

23）友景 肇, 境 幸二, 吉武一城, 秋田千芳, 田中 滋, 田中順三：日七ラ協 電子材料研究討論会 予稿 (1991)p. 55.

24）高橋智春, 渡辺正満, 一ノ瀬昇 : 日セラ協 電子 材料研究討論会予稿 (1991) p. 57 . 